\title{
Knowledge Management in Collaborative Manufacturing Food Companies Performances: Twin Impacts of Learning and Innovation
}

\author{
Hashem Salarzadeh Jenatabadi ${ }^{1}$, Che Wan Jasimah Wan Mohamed Radzi ${ }^{1}$, Suzana Ariff Azizan ${ }^{1}$, Maisarah Binti \\ Hasbullah $^{1}$, Mohd Zufri Mamat ${ }^{1} \&$ Peyman Babashamsi $^{2}$ \\ ${ }^{1}$ Department of Science and Technology Studies, Faculty of Science, University of Malaya, Jalan Universiti, \\ 50603 Kuala Lumpur, Malaysia \\ ${ }^{2}$ Department of Civil \& Structural Engineering, Faculty of Engineering, Universiti Kebangsaan Malaysia, 43600 \\ UKM Bangi, Selangor, Malaysia \\ Correspondence: Hashem Salarzadeh Jenatabadi, Department of Science and Technology Studies, Faculty of \\ Science, University of Malaya, Jalan Universiti, 50603 Kuala Lumpur, Malaysia. Tel: 6-037-967-4343. E-mail: \\ jenatabadi@um.edu.my
}

Received: November 11, 2015

Accepted: February 22, 2016

Online Published: June 18, 2016

doi:10.5539/masv10n8p161

URL: http://dx.doi.org/10.5539/masv10n8p161

The research is financed by (University of Malaya).

\begin{abstract}
The purpose of this approach is to establish the twin impacts of organizational innovation (OI) with organizational learning (OL) in the relation between knowledge management $(\mathrm{KM})$ and organizational performance (OP). 168 companies of manufacturing Food Company were chosen from Malaysia, Taiwan, China and path analysis is used to analyse the underlying hypotheses. The research framework under study contain four latent variables (OP; OL; KM; OI) and three observed indicators (firm type; firm size; firm age). Structural equation modelling include mediation and moderation analysis were used in this study. The obtained results support the literature regarding the relationship among these four constructs and prove that the combination of OI and OL is mediator in the linkage between KM and firm performance. Moreover, firm age, size and type are acting as moderators among the research latent variables. The introduced model can be consider as a basic framework for technology management modelling studies. Limitation and implications for future studies are discussed.
\end{abstract}

Keywords: firm innovation, organizational learning, company performance, knowledge management, path analysis, manufacturing food industry, technology management modelling

\section{Introduction}

In firm performance studies, researchers are seeking for effective indicators and perform statistical analysis to find the impact of the indicators on performance. Previous analyses confirmed the key role of KM (H. Lee \& Choi, 2003; Sung \& Choi, 2012), OL (Cho, Song, Yun \& Lee, 2013; López, Peón \& Ordás, 2005), and OI (Artz, Norman, Hatfield \& Cardinal, 2010; Gunday, Ulusoy, Kilic \& Alpkan, 2011) in improving OP. Moreover, the linkage among KM, OL, OP (Darroch, 2005; Darroch \& McNaughton, 2003; Hui, Radzi, Jenatabadi, Kheirollahpour \& Radu, 2013); KM, OI, OP (Hitt, Ireland \& Lee, 2000; Rashid \& Rashid, 2013); OI, OL, OP (Hui, Radzi, Jenatabadi, Abu Kasim \& Radu, 2013; Jiménez-Jiménez \& Sanz-Valle, 2010; Salim \& Sulaiman, 2011) have been proved by previous studies. However, few studies have determined the impact of KM on OP through some mediators such as OL and OI. The main gap of previous studies is that they considered OL and OI as distinctive mediator in the linkage between KM and company performance. Furthermore, the relationship between OL and OI has been proved by so many literatures. Therefore, the combination of OL and OI should be considered as the main mediator in the linkage between KM (as independent) and company performance (as dependent).

In the current study, structural equation modeling (SEM) has been used to illustrate casual impact of organizational characteristics on manufacturing companies' performances. Generally, SEM is a strong statistical methodology that combines statistical data and qualitative causal assumption to assess and evaluate the causal 
associations. SEM can effectively replace multiple regressions, covariance analysis, time series analysis, factor analysis, and path analysis, which means that it is possible to consider the aforementioned procedures as special cases of SEM. In other words, SEM is considered as an extension of the general linear model (GLM) of which the well-known multiple regression modelling is a part. The most significant of SEM advantages is its ability to enable the researcher to simultaneously model and examine the indirect and direct interrelationships that exist among multiple dependent and independent variables (Gefen, Straub \& Boudreau, 2000). This feature is a vital ability in the current research in which the model has an essential factor of mediation, i.e., a dependent variable, such as OL or OI, which, in the subsequent independent relationships, changes into an independent variable. After the effects of all other paths are taken into consideration, SEM assesses and evaluates each path coefficient separately. This feature makes SEM the most appropriate means for testing and estimating the role of the variables. As a result, the impact of a predictor factor is conveyed to a standard playing role of a mediator. In fact, SEM is an effective and optimal technique for checking and testing the relationships among mediator variables (Dhanaraj, Lyles, Steensma \& Tihanyi, 2004). The mediated effects form and strength may be dependent on some other factors and variables that can affect the existing hypothesized relationship among a group of variables. In this case, they are called moderators, which can usually be tested as effects of interaction (Aiken, West \& Reno, 1991). Examining the moderator effects enables a researcher to see if the effects of the experiment on individual subgroups are different (Donaldson, 2001). Therefore, the primary objective of this study is to illustrate the interaction of OL and OI as a mediator in the linkage between KM and company performance. The secondary objective is to illustrate company type, size and age acting as moderators in the relationship among four latent variables.

\section{Literature Review and Hypothesis}

\subsection{Knowledge Management}

Knowledge can be considered as a company's major resource as well as a decisive source of competitive gain (Gold, Malhotra \& Segars, 2001). Hence, those entrepreneurs with a high level of knowledge and information are able to achieve profit in the market. KM which is known as a section of knowledge is related to the usage of knowledge and the way an organization can acquire its aims (Ramachandran, Chong \& Ismail, 2009). Furthermore, it also can help to solve the complicated ambiguities in business (Anthes, 1998). Researchers introduced several kinds of KM in their research work such as capability-acquisition, conversion, application, and protection (Gold et al., 2001), create, transfer, assemble, integrate, and exploit (Teece, 2003), create, transfer, and use (Skyrme \& Amidon, 1998); capture, transfer, and use (DeLong, 1997); acquire, experiment, collaborate, and integrate (Leonard-Barton, 1995) and create and process (Ivers, 1998).

\subsection{Organizational Learning}

Learning ability is known as a human being's talent to adapt to the dynamic atmosphere around him. Every human is able to achieve new ideas and view through learning which leads him to new notions and understanding directing him to compelling decision in order to react efficiently and be able to have immediate self-correction (Argyris \& Schön, 1997). Learning's role and the influence enter to business and as a result, it now is a determining factor who shows the level of performance in organizational tasks.

According to the study by Pilar, Jose, and Ramon (2005), the knowledge and its formation, dispersion and combination in the companies are necessary strategic resources to organizational learning. In addition, organizational learning (OL) is known as an influential process constructed on knowledge signifying moving among various degrees of action, from the individual to the group, and later to the organizational degree and back again (Huber, 1991). Hence, based on the initial hypothesis of the present work, we can come to the conclusion that,

$\mathrm{H}_{1}$ : The influence of $\mathrm{KM}$ on OL will be positive in manufacturing food industry.

\subsection{Organizational Innovation}

Different types of definition of innovation have been recommended and this topic has been used in many studies such as entrepreneurship (C. Lee, Hallak \& Sardeshmukh, 2016), management/strategy (Gassmann, Frankenberger \& Csik, 2016), political science (Van Oudheusden, Charlier, Rosskamp \& Delvenne, 2015) and marketing (Sarkees, Luchs, Johnston \& Johnston, 2015; Yao, Xu, Jiang \& Zhang, 2015) in which organizational innovativeness is thoroughly examined and discussed. The studies and researches specifically carried out on the antecedents and consequences of effective KM are hardly empirical (Darroch \& McNaughton, 2002). The KM is often identified by the researchers as a significant antecedent of innovation. However, in the literature, effective KM has been identified as a way to improve innovation and performance. Many researches have been done on 
KM supporting KM to be antecedent of innovation. For this purpose, S. Liao and C. Wu (2009) have also studied the relationship between these two constructs. As Darroch (2005) research displayed, KM process positively affects innovation. Therefore, it can be concluded that the KM and innovation are closely interrelated. As a consequence, the second hypothesis can be defined as bellow:

$\mathrm{H}_{2}$ : The influence of KM on OI will be positive in food industry.

It should be mentioned that a company's learning efficiency plays a key role in innovation generation (Sinkula, Baker \& Noordewier, 1997). Although, innovation suggests generation, acknowledgment and the application of new ideas, procedures, outputs as well as services. Hence, organization intelligence is regarded as the use of new ideas and their implementation to the organizational management. The new ideas can be embodied in outputs, processes and management or the system of business (Weerawardena, O'Cass \& Julian, 2006).

In the study by Calantone, Cavusgil, and Zhao (2002), it was shown that considering the managers of American $\mathrm{R} \& \mathrm{D}$, the level of organizational innovativeness is based on the degree of the learning orientation of the company. Moreover, it was shown that if the learning orientation goes up, the organization's innovation degree increases (Weerawardena et al., 2006). Regarding all theses ideas, learning is considered as the prompter of innovations in any company. Consequently, the empirical tests validate and prove the relation of learning and organization intelligence suggesting that the influence of learning on OI is poitive. Hence, the third hypothesis is characterized as:

$\mathrm{H}_{3}$ : The influence of $\mathrm{OL}$ on $\mathrm{OI}$ will be positive in manufacturing food industry.

\subsection{Organizational Performance}

The interdisciplinary scholars concur that the organizational performance includes strategic planners as well as legal and financial problems, operations as organizational development. According to Hamon (2003), firm performance is considered as a factor estimating the quality of an enterprise as well as how it meets its aims and objectives. Hence, an OP can be assessed through the degree of effectiveness and efficiency in obtaining the goals (Robbins \& Coulter, 2002). In a research by Andersen (2006), it is mentioned that the notion of effectiveness as a ratio that needs to items to characterize and assess the effectiveness of obtaining goals such as return on assets. He continues that effectiveness is defined as the level of goal attainment such as the profitable aims achievement. To elaborate, it can be mentioned that the organizational performance makes the practical outputs and products of a company estimated against the originally expected findings.

Reviewing past literatures, many scholars conducted research to understand the relations among KM, OL, and OI with OP separately. Therefore, in this study we have the following hypotheses in manufacturing food industry;

$\mathrm{H}_{4}$ : The influence of $\mathrm{KM}$ on OP will be positive in manufacturing food industry.

$\mathrm{H}_{5}$ : The influence of OL on OP will be positive in manufacturing food industry.

$\mathrm{H}_{6}$ : The influence of OI on OP will be positive in manufacturing food industry.

Hence, as also supported in the previous studies, the influence of $\mathrm{KM}$ over OL will be significant effective. And consequently, OL will affect OI positively (Calantone et al., 2002; Weerawardena et al., 2006). Darroch (2003) is also concluded that the impact of KM over innovation has more influence on indirect linkage than direct relation. And from Liao, Fei, and Liu (2008), OL interconnects KM and OI together (S. H. Liao \& C. Wu, 2009). Also OL is acting as a mediator in the linkage between $\mathrm{KM}$ and company performance (S. Liao \& C. Wu, 2009). Therefore, it can be assumed that the main contribution of the study which is both OI and OL will serve as two interconnection mediators between KM and OP. In conclusion, the seventh hypothesis is that

$\mathrm{H}_{7}$ : Interaction of $\mathrm{OL}$ and $\mathrm{OI}$ is mediator between the linkage of $\mathrm{KM}$ and $\mathrm{OP}$ in manufacturing food industry.

\subsection{Moderating Effect of Company Type, Size and Age}

This article attempts to thoroughly analyse the likelihood of moderating impact of some internal variables such as firm age, size and industrial type on the relationships between the underlying latent variables. These variables are frequently cited in the literature as precursors for OL, OI, and OP and, according to some research outcomes, they have capability to moderate the relationships suggested in the current research study.

As widely reflected in the literature, the effect of size of a company is positive both on performance and innovation, since the biggest ones normally allocate more resources to be invested in innovation (Kimberly \& Evanisko, 1981). Furthermore, size is usually considered as a control variable in the studies relating to OI (Damanpour \& Schneider, 2006; Laforet, 2008; McDermott \& Prajogo, 2012) and OP (Hmieleski, Cole \& Baron, 
2010; Kimberly \& Evanisko, 1981; H. Wang, Tsui \& Xin, 2011). The age of a firm has also significant impact on OL, OI and OP (Hitt, Hoskisson \& Kim, 1997; Jiménez-Jiménez \& Sanz Valle, 2010). According to a study by Sørensen and Stuart (2000), experience and organizational competencies provided by age, help firms to develop their operations in a more efficient way, especially the operations related to innovation. Raw organizational management in some nascent firms can impede development of innovation as well. Therefore, age and size can lead to improvement of the innovation effects on performance and the impact of OL on both performance and innovation. As result, size and age may improve the effect of innovation on performance and the effect of OL on both innovation and performance.

In summary, firm size and age, moderate the relationship among four constructs together. We also added the firm type which can be grouped into private and public company in the study framework. This feature can be presented as another contribution of the paper. Thus, we have

$\mathrm{H}_{8}$ : Company type, size, and age are acting as a moderator in the linkage among $\mathrm{KM}$, OL, OI, and OP in manufacturing food companies.

\section{Method}

\subsection{Research Model}

Considering the above raised points, it can be understood that in this study a system perspective is employed in which KM as an initial input, combination of OL and OI as mediator and OP as output are taken into consideration. As per the reviewed literatures, the underlying research framework constructed by the present study is displayed in Figure 1.

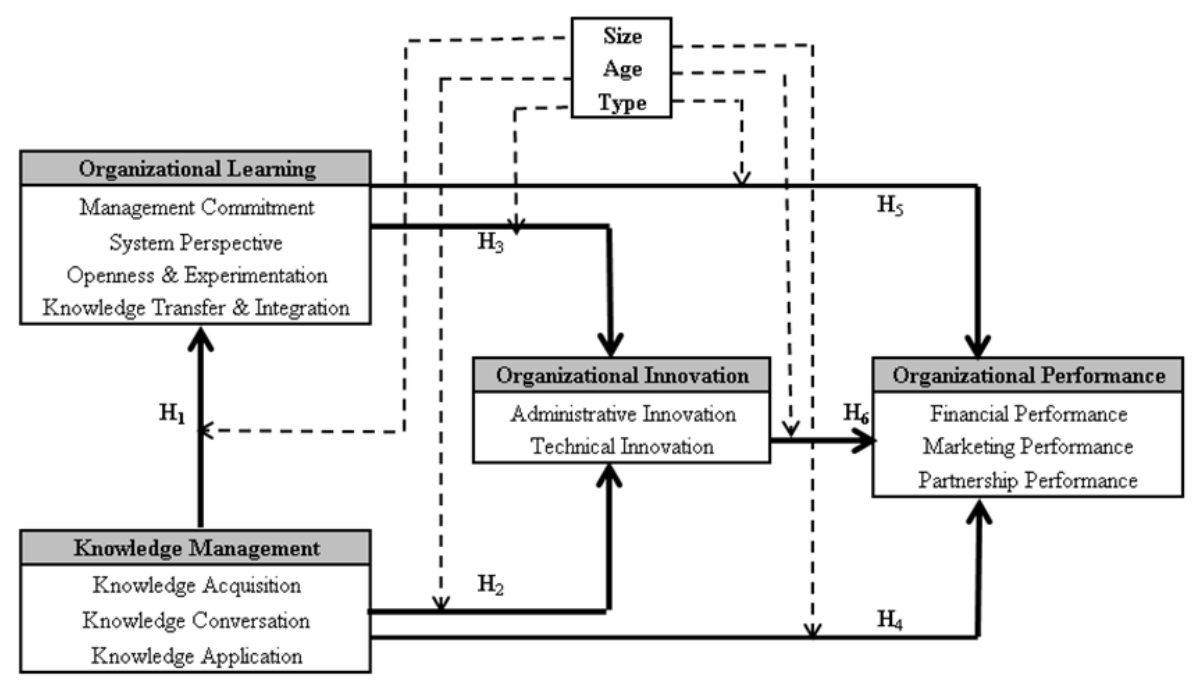

Figure 1. Research Framework

\subsection{Sampling}

In this study, quantitative survey applied to empirically analyses the research hypotheses. The data were collected during five months between October 2012 and February 2013. The proposed questionnaires were distributed among 250 randomly chosen from food manufacturing companies in three areas of China, Taiwan, and Malaysia. CEO, director/or senior manager were included as the key informants. By the end, 168 firms returned the completed questionnaires which delivered this paper with a response rate of $67 \%$.

\subsection{Measures}

In studies with SEM technique, the application of constructs has played a vital part of designing a survey instrument. In these types of studies, the researchers usually apply two or more measurement as indicators of a construct or latent variable. Developing new constructs is not an easy task and we need to define them from related theories and perform pre-testing to confirm their validity and reliability. In this regard, we consider 5 -point scale Likert-type measuring in this paper.

The objective of this study is to carry out a detailed investigation on the effect of KM on OP mediated by combination of OI and OL. Therefore, this research model covers four areas: KM, OL, OI, and OP. several 
studies have measured OP (Emden, Yaprak \& Cavusgil, 2005; Gunasekaran, Williams \& McGaughey, 2005; Venkatraman \& Ramanujam, 1987), KM (Cui, Griffith \& Cavusgil, 2005; Kulkarni, Ravindran \& Freeze, 2007; Nonaka \& Takeuchi, 1995), OI (Becheikh, Landry \& Amara, 2006; Damanpour, 1991; Torkzadeh, Koufteros \& Doll, 2005; C. L. Wang \& Ahmed, 2004), and OL (Edmondson, 1999; Hurley \& Hult, 1998; Jerez-Gomez, Céspedes-Lorente \& Valle-Cabrera, 2005). Gold et al. (2001), Jerez-Gomez et al. (2005), Damanpour (1991) and Emden et al. (2005) theories were used to measure research latent variables (See Table 1).

Table 1. Measure of Latent Variables

\begin{tabular}{|c|c|c|}
\hline Latent Variable & Theory & Indicators \\
\hline Organizational Performance & Emden et al. (2005) & $\begin{array}{ll}\text { 1. } & \text { Financial Performance } \\
\text { 2. } & \text { Marketing Performance } \\
\text { 3. } & \text { Partnership Performance }\end{array}$ \\
\hline Organizational Innovation & Damanpour (1991) & $\begin{array}{l}\text { 1. Administrative Innovation } \\
\text { 2. Technical Innovation }\end{array}$ \\
\hline Knowledge Management & Gold et al. (2001) & $\begin{array}{ll}\text { 1. } & \text { Knowledge Acquisition } \\
\text { 2. } & \text { Knowledge Conversation } \\
\text { 3. } & \text { Knowledge Application } \\
\end{array}$ \\
\hline Organizational learning & Jerez-Gomez et al. (2005) & $\begin{array}{l}\text { 1. Management Commitment } \\
\text { 2. System Perspective } \\
\text { 3. Openness and Experimentation } \\
\text { 4. Knowledge Transfer and Integration }\end{array}$ \\
\hline
\end{tabular}

Furthermore, we measured firm age as the number of years passed from the foundation of the company and firm size as the number of employees, part time or full time, of the company. For evaluating of company type, we use a dummy variable ( $0=$ private; $1=$ public).

\section{Results}

AMOS's 16 maximum likelihood program is utilized to examine the hypothetical model proposed, as presented in Figure 1. One of the major characteristics of the approach of this structural equation model is flexibility in interplaying between data and theory, and its capability to bridge the gap between empirical and theoretical knowledge for better understanding the realistic perception of the real world (Fornell \& Larcker, 1981). This kind of analysis, enables researchers to model based upon both manifest and latent variables, a feature suitably fitting for the model that has been hypothesized, in which the major portion of the constructs are made up of abstractions composed of unobservable phenomena. Moreover, in SEM, measurement errors are considered as multiple-group comparisons and variables with multiple indicators.

Figure 2 shows the structural model and Table 2 presents the overall model fit and the test of each hypothesis. As presented, the output indicates an adequate fit: $[\mathrm{RMSEA}]=0.042 ;[\mathrm{AGFI}]=0.932 ;[\mathrm{CFI}]=0.946 ;[\mathrm{GFI}]=0.904$; $[\mathrm{RFI}]=0.902 ;[\mathrm{NFI}]=0.925 ;[\mathrm{TLI}]=0.924[\mathrm{IFI}]=0.947$. All six research hypotheses are presented in Table 3 for details.

As hypothesized, KM exerted a direct effect on OL $\left(\beta_{1}=0.52\right)$ and OI $\left(\beta_{2}=0.23\right)$. In addition, OL has a strong direct effect on OI $\left(\beta_{3}=0.73\right)$. Moreover, OP in manufacturing food firms was significantly and positively predicted by $\mathrm{KM}\left(\beta_{4}=0.27\right)$, OL $\left(\beta_{5}=0.23\right)$, and $\mathrm{OI}\left(\beta_{6}=0.97\right)$.

Table 2. Parameter estimated and goodness of fit indices

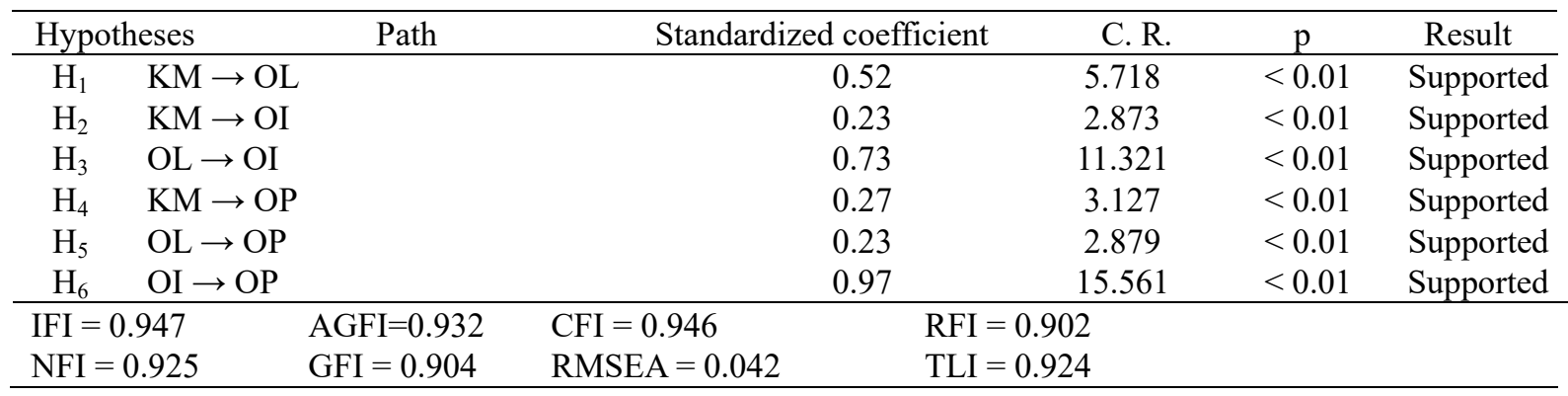




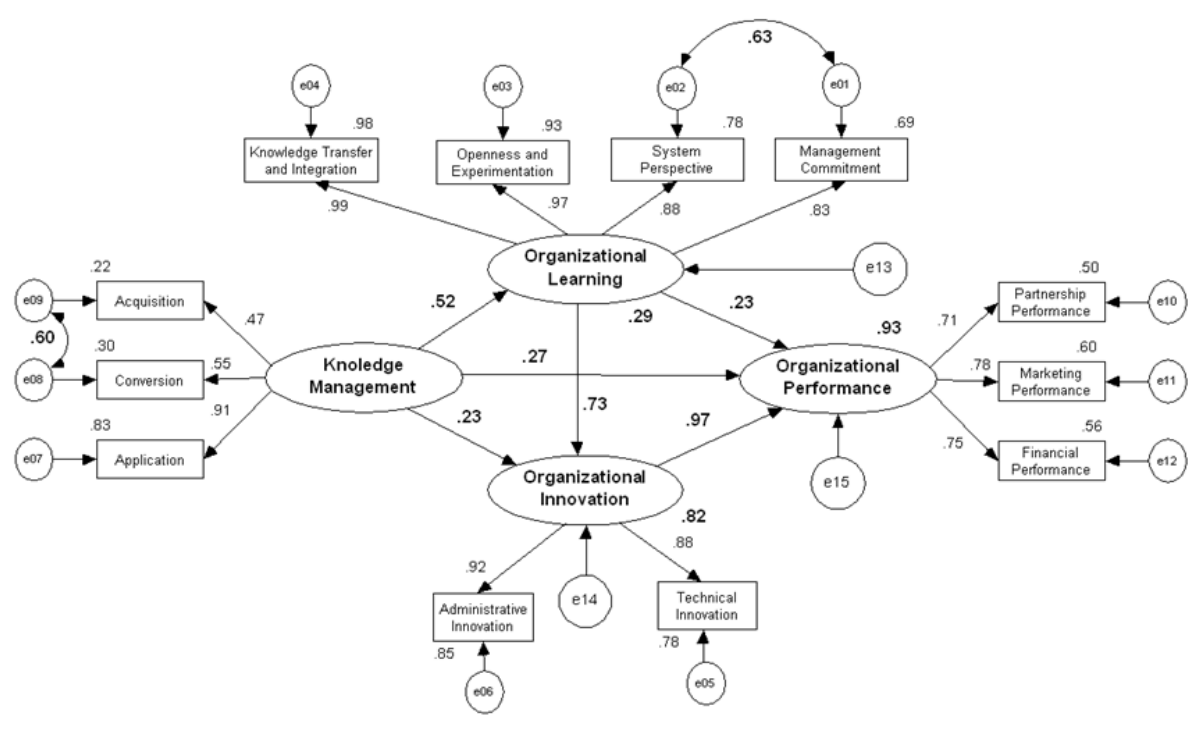

Figure 2. Structural model

However, the result reported in Table 3 supports path analysis, confirming each construct's direct, indirect, and total effects. Analysis provides sufficient support for the existence of direct and significant effect of KM as well as OP, i.e., $\beta=0.27$, C.R. $=3.127$, p-value $<0.05$, and existence of indirect effect which is 0.74 . As displayed in Figure 2, the indirect effect is significant (Mathieu \& Taylor, 2006) and bigger (Jiménez-Jiménez \& Sanz-Valle, 2010) in comparison to the direct effect. Considering these points, it can be confirmed that combination of OL and OI act as a partial mediation in the linkage between KM and OP in the research model. This, consequently, supports the seventh hypothesis $\left(\mathrm{H}_{7}\right)$.

Table 3. The analyzing direct, indirect, and total impact between variables.

\begin{tabular}{llccc}
\hline \multirow{2}{*}{ Outcome } & \multicolumn{2}{c}{ Input } & \multicolumn{3}{c}{ Standardized estimates } \\
\cline { 3 - 5 } Organizational Learning & & Direct & Indirect & Total \\
\cline { 3 - 5 } Organizational Innovation & Knowledge Management & 0.52 & - & 0.52 \\
& & & \\
& Knowledge Management & 0.23 & 0.12 & 0.35 \\
Organizational Performance & Organizational Learning & 0.93 & - & 0.93 \\
$\left(\mathrm{R}^{2}=.82\right)$ & Knowledge Management & 0.27 & 0.47 & 0.74 \\
& $\begin{array}{l}\text { Organizational Learning } \\
\text { Organizational Innovation }\end{array}$ & 0.32 & 0.54 & 0.84 \\
& & & - & 0.64 \\
\hline
\end{tabular}

Once the path analysis is done, the performance will be affected by KM through OL and OI. Therefore, interaction of OL and OI is believed to play the role of a significant mediator between KM and OP. This model, in comparison to the previous studies, is a new model, because KM is considered as essential input, based on which, food manufacturing companies are expected to exercise OL and OI effectively to be able to enhance the overall performance of the company.

Finally, $\mathrm{H}_{8}$, states that firm age, size, and type moderate the relationships between KM, OL, OI, and OP. To examine these moderating effects, this study uses the two-group comparison of SEM. This research divides the sample into two individuals along the median of the levels of each variable (with the exception of firm type, meanwhile this variable is dichotomous). One group consists of food companies possessing greater ranks for every moderator and the other one is food companies with lower ranks. Later, the investigation consisting of a double- group comparison to explore if there is any meaningful distinction in structural parameters between the mentioned companies with tow ranks of high and low or private and governmental. 
To confirm the organization's age, type and size distinctions among the regression weights, Critical Ratio (C.R.) test $(> \pm 1.96, p<.05)$ is able to be applied for obtaining the critical ration statics for the discrepancies of regression weights in higher and lower age subjects (R. Ho, 2006). Moreover, in a study by Arbuckle and Wothke (1999), it was observed that the critical ratio of an estimate pair examines the hypothesis in order to verify if both parameters are equal. The mentioned approach is redone to explore the three factors' possible moderating effects in the six relations of the study model. In Table 4, it was demonstrated that in spite of the fact that the relations of four major constructs are positive and remarkable for all the groups, the three of the measurement factors explored the intensity of the mentioned relations. Hence, the factors of size, age and type of the organization are the moderators in the study model that confirms the $\mathrm{H}_{8}$ of the present research.

Table 4. Moderation Analysis

\begin{tabular}{|c|c|c|c|c|}
\hline Linkage & Overall model & Low & High & $\begin{array}{l}\text { C.R. } \\
\text { (difference) }\end{array}$ \\
\hline \multicolumn{5}{|c|}{ Company Size } \\
\hline $\mathrm{KM} \rightarrow \mathrm{OL}$ & $0.52^{* * *}$ & $0.33 * * *$ & $0.82 * * *$ & $10.21 * * *$ \\
\hline $\mathrm{KM} \rightarrow \mathrm{OI}$ & $0.23^{* * *}$ & $0.21^{* *}$ & 0.05 & $8.76^{* * *}$ \\
\hline $\mathrm{OL} \rightarrow \mathrm{OI}$ & $0.73^{* * *}$ & $0.81 * * *$ & $0.29 * *$ & $16.65 * * *$ \\
\hline $\mathrm{KM} \rightarrow \mathrm{OP}$ & $0.27 * * *$ & $0.21^{* *}$ & $0.48 * * *$ & $9.72 * * *$ \\
\hline $\mathrm{OL} \rightarrow \mathrm{OP}$ & $0.23 * * *$ & $0.66^{* * *}$ & $0.16^{*}$ & $21.26^{* * *}$ \\
\hline $\mathrm{OI} \rightarrow \mathrm{OP}$ & $0.97 * * *$ & $0.33^{* *}$ & $0.88 * *$ & $25.73 * * *$ \\
\hline \multicolumn{5}{|c|}{ Company Age } \\
\hline $\mathrm{KM} \rightarrow \mathrm{OL}$ & $0.52^{* * *}$ & $0.11 *$ & $0.32 * *$ & $4.56^{* *}$ \\
\hline $\mathrm{KM} \rightarrow \mathrm{OI}$ & $0.23^{* * *}$ & $0.33^{* *}$ & $0.38^{* *}$ & 1.21 \\
\hline $\mathrm{OL} \rightarrow \mathrm{OI}$ & $0.73^{* * *}$ & $0.79 * * *$ & $0.31 * * *$ & $9.76^{* * *}$ \\
\hline $\mathrm{KM} \rightarrow \mathrm{OP}$ & $0.27 * * *$ & $0.41 * * *$ & $0.68 * * *$ & $11.43 * * *$ \\
\hline $\mathrm{OL} \rightarrow \mathrm{OP}$ & $0.23 * * *$ & $0.34 * * *$ & 0.03 & $19.56^{* * *}$ \\
\hline $\mathrm{OI} \rightarrow \mathrm{OP}$ & $0.97 * * *$ & $0.33 * * *$ & $0.54 * * *$ & $9.25 * * *$ \\
\hline \multicolumn{5}{|c|}{ Company Type } \\
\hline Linkage & Overall model & Governmental & Private & $\begin{array}{l}\text { C.R. } \\
\text { (difference) }\end{array}$ \\
\hline $\mathrm{KM} \rightarrow \mathrm{OL}$ & $0.52 * * *$ & $0.45^{* * *}$ & $0.62 * * *$ & $6.74 * * *$ \\
\hline $\mathrm{KM} \rightarrow \mathrm{OI}$ & $0.23 * * *$ & $0.31 * * *$ & $0.37 * * *$ & 0.87 \\
\hline $\mathrm{OL} \rightarrow \mathrm{OI}$ & $0.73 * * *$ & $0.65^{* * *}$ & 0.06 & $19.65^{* * *}$ \\
\hline $\mathrm{KM} \rightarrow \mathrm{OP}$ & $0.27 * * *$ & $0.59 * *$ & $0.23 * * *$ & $17.29 * * *$ \\
\hline $\mathrm{OL} \rightarrow \mathrm{OP}$ & $0.23 * * *$ & $0.43 * * *$ & $0.21 * *$ & $13.12 * * *$ \\
\hline $\mathrm{OI} \rightarrow \mathrm{OP}$ & $0.97 * * *$ & $0.56^{* * *}$ & $0.34 * * *$ & $7.34 * * *$ \\
\hline \multicolumn{5}{|c|}{$* \mathrm{P}$-value $<0.05 ; * * \mathrm{P}$-value $<0.01, * * * \mathrm{P}$-value $<.001$} \\
\hline
\end{tabular}

Finally, our data analysis prove that in manufacturing food companies, type, size and age of the company are acting as a significant moderator in the linkage between OL and OP. However, these moderating impacts are not always as expected in company management studies. In specific, in organizational study, they show that the positive impact between the linkages of OL over company performance is more intense in the group of organizations that are smaller, older, and belong to public organizations.

\section{Discussion}

This research developed a framework for studying KM, OL, OI, and firm performance for manufacturing food industries studies. The research model was examined using data gathered from China, Taiwan, and Malaysia. We illustrated that the combination of OL and OI is critical for KM and OP, which is improved the contribution of the study. Based on our data analysis, a number of guidelines can be suggested to the managers and researchers regarding the role of OI and OL.

According to our findings, in food industry, the linkage between KM and company performance is positive [coefficient $=0.27$; C.R. $=3.27 ; \mathrm{P}<0.01$ ] but this relationship can become stronger if organizations become bigger, older and belong to public companies, which is consistent with previous research in organizational studies. The relationship between OL and OP is positive [coefficient $=0.23$; C.R. $=2.879 ; \mathrm{P}<0.01$ ]. It proposes that the OL level in the firm is one of the deterministic criteria for evaluating its progress, success and development. Hence, the 
higher OL in an organization is, the higher performance level would become. Furthermore, in learning oriented organizations, high degrees of strategic abilities are achieved which make them capable for reaching and maintaining a level of competitive advantage leading to long term performance. Roughly speaking, in producing organizations achieving performance, success and competitive advantage require OL. This relation is stronger for smaller and younger organizations, and in public organizations. These results are only partially consistent with the previous literature. OI significantly impacts on OP [coefficient $=0.97$; C.R. $=15.561 ; \mathrm{P}<0.01$, which is confirmed by previous studies (Darroch, 2005; L.-A. Ho, 2011; McDermott \& Prajogo, 2012; Ndubisi \& Iftikhar, 2012). Specially, the current paper demonstrates that technical innovation has the highest factor loading; that means this element is the most important element influencing on overall innovation in food manufacturing industry in Malaysia, Taiwan, and China. The outcomes show that this relation has the stronger linkage between every two pair constructs. Therefore, this is the most effective way to improve OP is through appropriate and effective technical planning and implementation.

The modeling among KM, OL, OP; KM, OI, OP; OI, OL, OP have been proved by previous studies. They do believe for improving performance OL and OI are the most vital constructs and considered separately in their model. Moreover the relationship between OL and OI has been approved by previous studies (Bao, Chen \& Zhou, 2012; Salim \& Sulaiman, 2013). Therefore, in this research we contributed that KM can improve the firm performance through the combination of OI and OL. Hence, it could be claimed that once the strategies of KM are properly applied, facilitation of generating and applying novel and genius ideas, behaviors and policies to improve performances in food manufacturing companies would be possible.

As mentioned in the introduction section, this article contributes to the literature through analysis of the likelihood of moderating. The impact of firm size, age, and type on the relationships among KM, OL, OI, and OP are confirmed respectively. The main finding of this study is the stability of significance and positivity of these relationships regardless of the moderators levels, although their intensity changes. As suggested in literature, firm 's size by significant positive impact of OL on OI and OP is more significant in companies of smaller size. Large companies usually have access to more resources to be invested in OI. Thus, these companies may be less dependent on OL processes than smaller companies. As consistent with the previous studies, the outputs of this research reveal that age intensifies the linkage between OI and OL (Sørensen \& Stuart, 2000). The findings apparently demonstrate that age enables firms to develop organizational routines to be able to perform their activities with more efficiency and better performance. Nevertheless, younger companies suffer from missing consolidated routines, meaning that innovation needs further attention and work from the organizational learning process.

\section{Acknowledgement}

This research was funded by the University of Malaya, Kuala Lumpur, Malaysia under project number: RP027B-15HNE, RP027D-15HNE and RP007B-13HNE.

\section{References}

Aiken, L. S., West, S. G., \& Reno, R. R. (1991). Multiple regression: Testing and interpreting interactions: Sage Publications, Inc.

Andersen, J. A. (2006). Leadership, personality and effectiveness. The journal of socio-economics, 35(6), 1078-1091. http://dx.doi.org/10.1016/j.socec.2005.11.066

Anthes, G. H. (1998). Learning how to share. Computerworld, 32(8), 75-77.

Arbuckle, J. L., \& Wothke, W. (1999). Amos 4.0 user's guide. Chicago: SmallWaters.

Argyris, C., \& Schön, D. (1997). Organizational learning: a theory of action perspective. Reis (77/78), 345-348.

Artz, K. W., Norman, P. M., Hatfield, D. E., \& Cardinal, L. B. (2010). A longitudinal study of the impact of $\mathrm{R} \& \mathrm{D}$, patents, and product innovation on firm performance. Journal of Product Innovation Management, 27(5), 725-740. http://dx.doi.org/10.1111/j.1540-5885.2010.00747.x

Bao, Y., Chen, X., \& Zhou, K. Z. (2012). External learning, market dynamics, and radical innovation: Evidence from China's high-tech firms. Journal of Business Research, 65(8), 1226-1233. http://dx.doi.org/10.1016/j.jbusres.2011.06.036

Becheikh, N., Landry, R., \& Amara, N. (2006). Lessons from innovation empirical studies in the manufacturing sector: A systematic review of the literature from 1993-2003. Technovation, 26(5), 644-664. http://dx.doi.org/10.1016/j.technovation.2005.06.016

Calantone, R. J., Cavusgil, S. T., \& Zhao, Y. (2002). Learning orientation, firm innovation capability, and firm 
$\begin{array}{llll}\text { performance. } \quad \text { Industrial } & \text { Marketing }\end{array}$ http://dx.doi.org/10.1016/S0019-8501(01)00203-6

Cho, S. H., Song, J. H., Yun, S. C., \& Lee, C. K. (2013). How the Organizational Learning Process Mediates the Impact of Strategic Human Resource Management Practices on Performance in Korean Organizations. Performance Improvement Quarterly, 25(4), 23-42. http://dx.doi.org/10.1002/piq.21127

Cui, A. S., Griffith, D. A., \& Cavusgil, S. T. (2005). The influence of competitive intensity and market dynamism on knowledge management capabilities of multinational corporation subsidiaries. Journal of International Marketing, 32-53. http://dx.doi.org/10.1509/jimk.13.3.32

Damanpour, F. (1991). Organizational innovation: A meta-analysis of effects of determinants and moderators. Academy of Management Journal, 555-590. http://dx.doi.org/10.2307/256406

Damanpour, F., \& Schneider, M. (2006). Phases of the adoption of innovation in organizations: Effects of environment, organization and top Managers1. British Journal of Management, 17(3), 215-236. http://dx.doi.org/10.1111/j.1467-8551.2006.00498.x

Darroch, J. (2003). Developing a measure of knowledge management behaviors and practices. Journal of Knowledge Management, 7(5), 41-54.

Darroch, J. (2005). Knowledge management, innovation and firm performance. Journal of Knowledge Management, 9(3), 101-115. http://dx.doi.org/10.1108/13673270510602809

Darroch, J., \& McNaughton, R. (2002). Examining the link between knowledge management practices and types of innovation. Journal of intellectual capital, 3(3), 210-222. http://dx.doi.org/10.1108/14691930210435570

Darroch, J., \& McNaughton, R. (2003). Beyond market orientation: knowledge management and the innovativeness of New Zealand firms. European Journal of Marketing, 37(3/4), 572-593. http://dx.doi.org/10.1108/03090560310459096

DeLong, D. (1997). Building The Knowledge-Based Organization: How Culture Drives Knowledge Behaviors. Center for Business Innovation. Ernst \& Young LLP. http://dx.doi.org/Working Paper

Dhanaraj, C., Lyles, M. A., Steensma, H. K., \& Tihanyi, L. (2004). Managing tacit and explicit knowledge transfer in IJVs: the role of relational embeddedness and the impact on performance. Journal of International Business Studies, 428-442. http://www.jstor.org/stable/3875203

Donaldson, S. I. (2001). Mediator and moderator analysis in program development. Handbook of program development for health behavior research and practice, 470-496. $\mathrm{http}: / / \mathrm{dx}$. doi.org/10.1016/j.jbusres.2003.10.008

Edmondson, A. (1999). Psychological safety and learning behavior in work teams. Administrative science quarterly, 44(2), 350-383. http://dx.doi.org/10.2307/2666999

Emden, Z., Yaprak, A., \& Cavusgil, S. T. (2005). Learning from experience in international alliances: antecedents and firm performance implications. Journal of Business Research, 58(7), 883-892. http://dx.doi.org/10.1016/j.jbusres.2003.10.008

Fornell, C., \& Larcker, D. F. (1981). Evaluating structural equation models with unobservable variables and measurement error. Journal of marketing research, 18(1), 39-50. http://dx.doi.org/10.2307/3151312

Gassmann, O., Frankenberger, K., \& Csik, M. (2016). Innovation Strategy: From new Products to Business Model Innovation Business Innovation: Das St. Galler Modell (pp. 81-104): Springer.

Gefen, D., Straub, D., \& Boudreau, M. C. (2000). Structural equation modeling and regression: Guidelines for research practice. Communications of the Association for Information Systems, 4(1), 7.

Gold, A. H., Malhotra, A., \& Segars, A. H. (2001). Knowledge management: an organizational capabilities perspective. Journal of Management Information Systems, 18(1), 185-214.

Gunasekaran, A., Williams, H. J., \& McGaughey, R. E. (2005). Performance measurement and costing system in new enterprise. Technovation, 25(5), 523-533. http://dx.doi.org/10.1016/j.technovation.2003.09.010

Gunday, G., Ulusoy, G., Kilic, K., \& Alpkan, L. (2011). Effects of innovation types on firm performance. International Journal of Production Economics, 133(2), 662-676. http://dx.doi.org/10.1016/j.ijpe.2011.05.014

Hamon, T. T. (2003). Organizational effectiveness as explained by social structure in a faith-based business network organization. Regent University. 
Hitt, M. A., Hoskisson, R. E., \& Kim, H. (1997). International diversification: Effects on innovation and firm performance in product-diversified firms. Academy of Management Journal, 40(4), 767-798. http://dx.doi.org/10.2307/256948

Hitt, M. A., Ireland, R. D., \& Lee, H.-u. (2000). Technological learning, knowledge management, firm growth and performance: an introductory essay. Journal of Engineering and Technology Management, 17(3), 231-246. http://dx.doi.org/10.1016/S0923-4748(00)00024-2

Hmieleski, K. M., Cole, M. S., \& Baron, R. A. (2010). Linking Shared Authentic Leadership to Firm Performance: A Study of New Venture Top Management Teams. Frontiers of Entrepreneurship Research, $30(5), 1$.

Ho, L. A. (2011). Meditation, learning, organizational innovation and performance. Industrial Management \& Data Systems, 111(1), 113-131. http://dx.doi.org/10.1108/02635571111099758

Ho, R. (2006). Handbook of univariate and multivariate data analysis and interpretation with SPSS: CRC Press.

Huber, G. P. (1991). Organizational learning: The contributing processes and the literatures. ORGANIZATION SCIENCE, 2(1), 88-115. http://dx.doi.org/10.1287/orsc.2.1.88

Hui, H., Radzi, C. W. J. W. M., Jenatabadi, H. S., Abu Kasim, F., \& Radu, S. (2013). Influence of Organizational Learning and Innovation on Organizational Performance in Asian Manufacturing Food Industry. Asian Journal of Empirical Research, 3(8), 962-971.

Hui, H., Radzi, C. W. J. W. M., Jenatabadi, H. S., Kheirollahpour, M., \& Radu, S. (2013). Impact of Knowledge Management and Organizational Learning on Different Dimensions of Organizational Performance: A Case Study of Asian Food Industry. Interdisciplinary Journal of Contemporary Research In Business, 5(3), p148.

Hurley, R. F., \& Hult, G. T. M. (1998). Innovation, market orientation, and organizational learning: an integration and empirical examination. The Journal of marketing, 42-54.

Ivers, J. (1998). Bringing out brilliance: enabling knowledge creation in the Notes/Domino environment. Enterprise Solutions, 10, 24-27.

Jerez-Gomez, P., Céspedes-Lorente, J., \& Valle-Cabrera, R. (2005). Organizational learning capability: a proposal of measurement. Journal of Business Research, 58(6), 715-725.

Jiménez-Jiménez, D., \& Sanz-Valle, R. (2010). Innovation, organizational learning, and performance. Journal of Business Research. http://dx.doi.org/10.1016/j.jbusres.2010.09.010

Kimberly, J. R., \& Evanisko, M. J. (1981). Organizational innovation: The influence of individual, organizational, and contextual factors on hospital adoption of technological and administrative innovations. Academy of Management Journal, 24(4), 689-713. http://dx.doi.org/10.2307/256170

Kulkarni, U. R., Ravindran, S., \& Freeze, R. (2007). A knowledge management success model: theoretical development and empirical validation. Journal of Management Information Systems, 23(3), 309-347. http://dx.doi.org/10.2753/MIS0742-1222230311

Laforet, S. (2008). Size, strategic, and market orientation affects on innovation. Journal of Business Research, 61(7), 753-764. http://dx.doi.org/10.1016/j.jbusres.2007.08.002

Lee, C., Hallak, R., \& Sardeshmukh, S. R. (2016). Innovation, entrepreneurship, and restaurant performance: A higher-order structural model. Tourism Management, 53, 215-228. doi:10.1016/j.tourman.2015.09.017

Lee, H., \& Choi, B. (2003). Knowledge management enablers, processes, and organizational performance: an integrative view and empirical examination. Journal of Management Information Systems, 20(1), 179-228. http://dx.doi.org/10.1080/07421222.2003.11045756

Leonard-Barton, D. (1995). Wellsprings of Knowledge: Building \& Sustainint the Sources of Innovation: Harvard Business Press.

Liao, S.-h., Fei, W. C., \& Liu, C. T. (2008). Relationships between knowledge inertia, organizational learning $\begin{array}{llll}\text { and } \quad \text { organization } & \text { innovation. }\end{array}$ http://dx.doi.org/10.1016/j.technovation.2007.11.005

Liao, S., \& Wu, C. (2009). The Relationship among Knowledge Management, Organizational Learning, and Organizational Performance. International Journal of Business and Management, 4(4), P64. http://dx.doi.org/10.5539/ijbm.v4n4p64

Liao, S. H., \& Wu, C. (2009). System perspective of knowledge management, organizational learning, and 
organizational innovation. Expert Systems with Applications. http://dx.doi.org/10.1016/j.eswa.2009.06.109

López, S. P., Peón, J. M. M., \& Ordás, C. J. V. (2005). Organizational learning as a determining factor in business performance. Learning Organization, The, 12(3), 227-245. http://dx.doi.org/10.1108/09696470510592494

Mathieu, J. E., \& Taylor, S. R. (2006). Clarifying conditions and decision points for mediational type inferences in organizational behavior. Journal of Organizational Behavior, 27(8), 1031-1056. http://dx.doi.org/10.1002/job.406

McDermott, C. M., \& Prajogo, D. I. (2012). Service innovation and performance in SMEs. International Journal of Operations \& Production Management, 32(2), 216-237. http://dx.doi.org/10.1108/01443571211208632

Ndubisi, N. O., \& Iftikhar, K. (2012). Relationship between entrepreneurship, innovation and performance: Comparing small and medium-size enterprises. Journal of Research in Marketing and Entrepreneurship, 14(2), 214-236. http://dx.doi.org/10.1108/14715201211271429

Nonaka, I., \& Takeuchi, H. (1995). The knowledge-creating company: How Japanese companies create the dynamics of innovation: Oxford University Press, USA.

Pilar, J. G., Jose, C. L., \& Ramon, V. C. (2005). Organizational learning capability: A proposal of measurement. Journal of Business Research, 58(6), 715-725.

Ramachandran, S. D., Chong, S. C., \& Ismail, H. (2009). The practice of knowledge management processes: A comparative study of public and private higher education institutions in Malaysia. VINE, 39(3), $203-222$. http://dx.doi.org/10.1108/03055720911003978

Rashid, Y., \& Rashid, A. (2013). An exploratory study examining the influence of Customer Knowledge Management on Customer Acquisition Performance and Organizational Learning. International Journal of Knowledge and Research in Management and E-Commerce, 3(2). http://rgsociety.org/journals/index.php/ijkrm/article/view/378

Robbins, S. P., \& Coulter, M. (2002). Management, 7’'edition: Prentice Hall Inc., New Jersey.

Salim, I. M., \& Sulaiman, M. (2011). Organizational learning, innovation and performance: a study of Malaysian small and medium sized enterprises. International Journal of Business and Management, 6(12), p118. http://dx.doi.org/10.5539/ijbm.v6n12p118

Salim, I. M., \& Sulaiman, M. (2013). Examination of the relationship between organisational learning and firm's product innovation. International Journal of Innovation and Learning, 13(3), 254-267. http://dx.doi.org/10.1504/IJIL.2013.052896

Sarkees, M., Luchs, R., Johnston, W., \& Johnston, W. (2015). The influence of marketing and innovation investments on alliance type choice. Journal of Business \& Industrial Marketing, 30(5).

Sinkula, J. M., Baker, W. E., \& Noordewier, T. (1997). A framework for market-based organizational learning: linking values, knowledge, and behavior. Journal of the Academy of Marketing Science, 25(4), 305-318. http://link.springer.com/article/10.1177/0092070397254003

Skyrme, D. J., \& Amidon, D. M. (1998). New measures of success. Journal of Business Strategy, 19(1), $20-24$. http://dx.doi.org/10.1108/eb039905

Sørensen, J. B., \& Stuart, T. E. (2000). Aging, obsolescence, and organizational innovation. Administrative science quarterly, 45(1), 81-112. http://dx.doi.org/10.2307/2666980

Sung, S. Y., \& Choi, J. N. (2012). Effects of team knowledge management on the creativity and financial performance of organizational teams. Organizational Behavior and Human Decision Processes, 118(1), 4-13. http://dx.doi.org/10.1016/j.obhdp.2012.01.001

Teece, D. (2003). Capturing value from knowledge assets: the new economy, markets for know-how and intangible assets. Essays on Technology Management and Policy, 47-75. http://dx.doi.org/10.2307/41165943

Torkzadeh, G., Koufteros, X., \& Doll, W. J. (2005). Confirmatory factor analysis and factorial invariance of the impact of information technology instrument. Omega, 33(2), 107-118. http://dx.doi.org/10.1016/j.omega.2004.03.009

Van Oudheusden, M., Charlier, N., Rosskamp, B., \& Delvenne, P. (2015). Broadening, deepening, and governing innovation: Flemish technology assessment in historical and socio-political perspective. Research policy, 
44(10), 1877-1886. http://dx.doi.org/10.1016/j.respol.2015.06.010

Venkatraman, N., \& Ramanujam, V. (1987). Planning system success: A conceptualization and an operational model. Management science, 33(6), 687-705.

Wang, C. L., \& Ahmed, P. K. (2004). The development and validation of the organisational innovativeness construct using confirmatory factor analysis. European Journal of Innovation Management, 7(4), 303-313.

Wang, H., Tsui, A. S., \& Xin, K. R. (2011). CEO leadership behaviors, organizational performance, and employees' attitudes. The Leadership Quarterly. http://dx.doi.org/10.1016/j.leaqua.2010.12.009

Weerawardena, J., O'Cass, A., \& Julian, C. (2006). Does industry matter? Examining the role of industry structure and organizational learning in innovation and brand performance. Journal of Business Research, 59(1), 37-45. http://dx.doi.org/10.1016/j.jbusres.2005.02.004

\section{Copyrights}

Copyright for this article is retained by the author(s), with first publication rights granted to the journal.

This is an open-access article distributed under the terms and conditions of the Creative Commons Attribution license (http://creativecommons.org/licenses/by/3.0/). 